\title{
THE DEVELOPMENT OF ISLAMIC SOCIETY BASED ON CELESTIAL BUSINESS
}

\author{
Agus Ahmad Safei \\ Universitas Islam Negeri (UIN) Sunan Gunungdjati, Bandung \\ e-mail: agusafe@yahoo.com
}

\begin{abstract}
Empirically, Islamic society in Indonesia - as the majority of the populationhasnot been able to compete with the various advantages possessed by Islamic societies in other countries, particularly in the developed ones. Academically, the conceptual references on the development of Islamic society are relatively hard to find. These facts warrant both empirical and academic efforts to develop the concepts and formulas of Islamic society development, especially regarding its economical aspect. This report will further describe the importance of a formula for developing Islamic society, based on celestial business (al-mubāya'ah alsamāwiyyah), and how it can be a solution to the problem of economical disadvantages in Islamic societies. This research used literary method that conducted by analyzing various literatures relevant with the topic of the research. The findings show that conceptually, the celestial business (business with God) formula is relevant for the development of the economic aspect of Islamic societies. This formula offers equilibrium between the satisfaction of material and spiritual needs, or the physical and spiritual needs. On the higher level, it can be an alternative formula to develop the economic aspect of any Islamic society.
\end{abstract}

\begin{abstract}
Secara empirik, masyarakat Islam Indonesia — sebagai penduduk mayoritas— masih jauh dari berbagai keunggulan dibandingkan dengan sesama umat dari negaranegara lain, terutama negara-negara maju. Secara akademik, referensi terkait dengan rujukan konseptual tentang pengembangan masyarakat Islam juga relatif sulit ditemukan. Fakta ini menuntut adanya ikhtiar empirik dan akademik untuk melahirkan berbagai formula pengembangan masyarakat Islam, khususnya pada aspek ekonomi. Tulisan ini memaparkan pentingnya formula pengembangan masyarakat Islam yang bertumpu pada "bisnis langitan" (al-mubāya'ah al-samāwiyyah). Pada level yang lebih luas formula ini dapat menjadi solusi atas problem ketertinggalan ekonomi masyarakat Islam. Penelitian ini menggunakan studi kepustakaan dengan berbagai bentuk literatur yang diposisikan setara terkait dengan topik utama penelitian. Hasil penelitian menunjukkan bahwa secara konseptual, formula "celestial business" (berbisnis bersama Tuhan) relevan untuk diterapkan dalam pengembangan masyarakat Islam pada aspek ekonomi. Formula ini menawarkan keseimbangan antara pemenuhan kebutuhan aspek material dan spiritual, jasmani dan ruhani. Lebih lanjut, formula ini dapat menjadi formula alternatif dalam upaya pengembangan ekoomi masyarakat Islam.
\end{abstract}$$
\text { *** }
$$

Keywords: formula; celestial business; development; Islamic society' equilibrium 


\section{A. Preface}

Islam is essentially a religion of empowerment and development. ${ }^{1}$ In Islamic view, empowerment should be a never-ending movement, which reflect the paradigm of Islam as the religion of movement or changes. ${ }^{2}$ In the context of Indonesia, Islamic society, as the majority of population, is still far behind Islamic societies in other countries.

Meanwhile, in the context of global relation, Islamic world is practically the least advanced part in the world, compared with other big religions. Islamic countries are left behind the Protestant countries of Northern Europe, North America, Australia, and New Zealand; the Roman Catholic countries of South Europe and South America; the Orthodox Catholic countries of Eastern Europe; the Jewish Israel; the Hindu India; the Buddhist-Confucians China; or the Buddhist-Taoist Japan. Practically, there is no big religion in the world whose advancement in science and economy is lower than that of Islam. This facts requires more systematic and continuous development efforts to produce highquality Islamic society; both academic and empirical efforts.

Empirically, the quality and competitiveness of Indonesian Islamic society are far from what is expected. This situation will lead to its failure to compete in those fields, resulting in scientific poverty (inability and unwillingness to deal with scientific advancement and technological development), social poverty (becoming more alienated, marginalized, and uncritical), moral poverty (becoming more hedonistic and ignorant of traditional values, particularly religion), methodological poverty (being slow in learning and accessing information in the super-fast pace age), and economic poverty (having no opportunity at all).

The discrepancy between the reality of the Islamic society on one hand and the normative ideal of Islamic teaching on the other hand bring forth some concerns, which lead to the formulation of empowerment and development model for Islamic society. Conceptually, the model and formula of Islamic

${ }^{1}$ See: QS. al-Mā'ūn [107]: 103.

2See: QS. al-Ra'du [13]: 11. 
society development are very rare; as evident in the scarcity of books or other forms of references on the topic.

In a simple term, Islamic Society Development can be formulated as a system of real actions which provide an alternative to solve the social, economic, and environmental problems of society from Islamic perspective. Therefore, Islamic society development is an empirical model to develop individual and collective behaviors in the dimension of their best works, focusing on solving the problems faced by society.

One of the most prominent aspects in which Islamic society left behind from other religions is the economy. Thus, economy becomes one of the aspects that will be focused on the development of Islamic society. It is important to conduct studies empirically and conceptually on various models and strategies of economic development in Islamic society. In the field of economy, free market and regional and international cooperation are the new norms. In fact, Indonesia has just become the member of ASEAN Economic Community, whose primary characteristics are competition and free market, since the early 2016.

This change in economic structure will definitely alter the structure of life in any society. It will need good and qualified people to compete with foreigners . If the requirements are not fulfilled, Islamic society will become what is called proletarian $^{3}$ living in modern age.

Regardless of this bad situation, there is still hope of changes, that Islamic society will regain the more dynamic and more authentic Islamic teaching. Since the early 2000's, many economic discourses have shifted to a more practical domain. As an '-ism' (ideology), the two big ideologies of economic world - the capitalism and the socialism - were considered fail to realize their promise to provide prosperity for the people.

Capitalism only leads to diametric economic irony. While it only needs 80 billion dollars to subsidize healthcare and sanitation facilities in sub-Saharan countries, about 130 billion dollars is spent in America alone for cosmetic needs of its people. When around 100 billion dollars is needed to subsidize education

\footnotetext{
${ }^{3}$ The term proletarian, proposed by Alfin Toffler, is paired with the term cognitarian. The former refers to the workers that tends to use their muscles more than their brain, while the latter refers to skilled workers that tends to utilize their cognitive capacity, and are always ready to upgrade their skills and knowledge. On this point, see, Jalaluddin Rakhmat, Catatan Kang Jalal: Visi Media, Politik, dan Pendidikan (Bandung: Rosdakarya, 1997), p. 373.
} 
in developing countries, around 133 billion dollars is wasted to satisfy European need of ice cream. ${ }^{4}$

On the other hand, socialism, which is considered as the antithesis of capitalism, also failed to provide promising economic prosperity. In countries with communism ideology, such as Vietnam and Cuba, prosperity is just a shared utopia; a dream that cannot be realized. China is regarded as an exception of the rule because it does not implement socialism economy in its system.

Amidst such ideological uncertainty, global economy tends to shift into something more practical. The concepts of 'business and entrepreneurship' are re-embraced as an alternative to realize economic prosperity that many people have been dreaming about.

Entrepreneurship in this study is what William J. Bamoul described as the creative and innovative efforts to create new independent and future-oriented field of creation. Entrepreneurship also requires new formulation and invention that, as Bamoul wrote, "Substantially different, depending on the type of organization that is being started." 5

At this stage, as many world economists, including John Perkins ${ }^{6}$, believe, business and entrepreneurship that requires creativity and empowerment of potentials can be the third way or the mid-way to solve the current problems of global economy, particularly in an Islamic society. Surely, the business must be inseparable from the celestial or heavenly values. Should such business, technically called 'celestial business,' succeed to be the concept that modern society refers to, it will be the new formula which will bring equilibrium to the world. The next problem is whetherthe concept of Celestial Business that refers to the practices of Muhammad can be widely formulated into a new way to practice economy.

This paper will reveal the result of conceptual analysis of Islamic society development models, focusing on the necessity to develop celestial business in such society. Furthermore, it will describe the importance of a formula for

\footnotetext{
${ }^{4}$ Amien Rais, Agenda Mendesak Bangsa: Selamatkan. Indonesia (Yogyakarta: PPSK, 2003).

${ }^{5}$ Wiliam J. Bamoul, R. E. Litian, C.J. Schramm, Good Capitalism, Bad Capitalism (New Haven \& London: Yale University Press, 2005), p. 23.

6John Perkins, Confession of Economic Hitman (London, Routledge, 2007).
} 
developing Islamic society that is based on celestial business (al-mubaya'ah assamawiyah) in the society, and how such formula can, in a wider level, be a solution for the problems of economic disadvantages of the society. Conceptually, the result of this study will enrich and offer an alternative to the models of Islamic society development in the field of economy, focusing particularly on the empowerment of celestial business.

Methodologically, this is a literary study conducted by analyzing various literature, including books, documents, and reports of previous studies. All these documents are considered equal, depending on their relevancy to the topic of the study. Data are collected through identification of discourses in books, articles, magazines, journals, and websites, to discover variables relevant with the topic discussed.

\section{B. Concept of Celestial Business}

According to Abdul Munir Mulkhan7, the concept of Islamic society development is a democratic attempt to improve quality of life as part of the empowerment of society in solving objectives problems of life. Through the dissemination of such problem solving and society development strategy, even the smallest Islamic society can be developed into a social community that possesses internal ability and improves independently to solve its own problems.

In this global age, with its open society, 8 there are great and fundamental changes, including in the fields of business and economy. 'Business', which has always been oriented to the satisfaction of material (physical) needs, turns out creating more problems while still unable to provide final and sufficient solutions. Regarding to this, Robert Holden provided us with a critical and quite interesting note: 9

\footnotetext{
${ }^{7}$ Abdul Munir Mulkhan, Teologi Kebudayaan (Yogyakarta: Sipress, 1995), p. 27.

8 The forming of 'global society' with its cultural characteristics has brought some derivations or implications. One of them is what Theodore Adorno called commodity society. It is a society in which the production of goods is no longer for the purpose of satisfying human needs and wants, but for the purpose of making profit. In commodity society, human needs are only satisfied incidentally. Another implication of this global society is the existence of the consumer society. For further information concerning this, see Idy Subandi Ibrahim (ed.) Ectasy Gaya Hidup: Kebudayaan Pop dalam Masyarakat Komoditas Indonesia (Bandung: Mizan, 1997), p. 13-56.

${ }_{9}^{9}$ Robert Holden, Success Intelligence (Bandung: Mizan, 2005), p. 287.
} 
"... modern people pursue success by following a workaholic and super-busy lifestyle, which ends up in depression, broken home, meaningless life, stroke, hypertension ... pursuit of success should have been accompanied by satisfying the spiritual, not merely the physical, needs."

The idea of Celestial Business emerges from situation that is deprived of spiritual values, that pursuit of happiness requires equilibrium between the material and spiritual, physical and psychologicalsuccess. This is mentioned in al-Qur'an:10

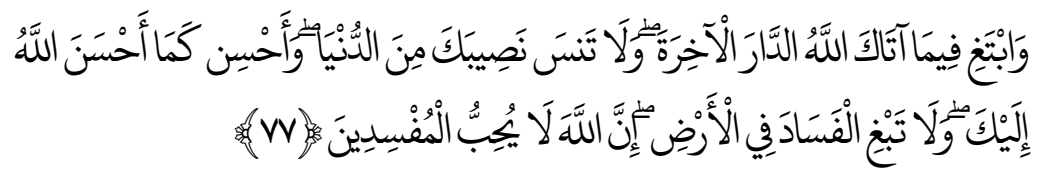

"But seek, through that which Allah has given you, the home of the Hereafter; and [yet], do not forget your share of the world. And do good as Allah has done good to you. And desire not corruption in the land. Indeed, Allah does not like corrupters."

It is an undisputable truth that the economic discrepancy nowadays creates imperialism on one hand and impoverishment on the other hand. This imbalance occurs when the economy no longer serves as the tool for human welfare -which has social orientation, but has changed into the way for modern lifestyle - which has individual orientation. ${ }^{11}$

Conceptually, the term Celestial Business means a business in which divine values are embedded. This concept is a result of reflective interpretation of the previously mentioned Surah al-Qasas verse 77. The phrase "wa lâ tabghi alfasâda fi al-ardhi" (and desire not corruption in the land), according to Quraish Shihab ${ }^{12}$, refers to the prohibition to hurt one's self and others, as well as doing things that may bring destruction.

The subject "al-mufsidûn" (people who do corruption that Allah dislikesas mentioned at the end of the verse) are people who see the earth and treat it only to satisfy his own material needs. The land (the world) is regarded as material object to be exploited and coopted for the satisfaction of his needs.

10See: QS. al-Qașas [28]: 77.

${ }^{11}$ David Chaney, Lifestyles: Sebuah Pengantar Komprehensif(Yogyakarta: Jalasutra, 1996).

${ }^{12}$ Quraish Shihab, Membumikan al-Quran (Bandung: Mizan, 2005), p. 211. 
This perspective is only possessed by those with only material, worldly, or physical consideration, while ignoring the spiritual aspects or the celestial orientation. When the spiritual aspect is ignored, their attitude and action toward earth and themselves become merely 'destruction' (fasad), as Holder stated.

Regarding the concept of Celestial Business, the Prophet Muhammad is the best example the history can provide. In the opinion of Karen Armstrong13, Muhammad is an extraordinary genius. When he died in 632 A.D., he had managed to unite almost all Arabian tribes, created an imperium that stretched from Himalaya to Perenia, and built a unique civilization.

It is important to see Muhammad as a man. He did not become a prophet overnight. His process of transformation from a mere man to a prophet was a long journey, full of struggles similar to those of any other men. He struggled to be honest, diligent, hardworking, and contemplative. He struggled to broaden his perspectives. ${ }^{14}$

All his knowledge about alternative values did not come 'free' from God. He 'bought' it with long and tiring conducts. Muhammad fasted longer, bow to God hundreds time longer, and worked harder than everyone else. However, he did not all those things greedily. Rather, all his conducts were those of a man chasing divine blessing.

In fact, as Haekal stated ${ }^{15}$, God has educated Muhammad with the perfect education. Muhammad put all his heart to walk the straight path, to obey the Eternal Good. He gave all his heart to Allah so that he could guide his people who were in a state of confusion.

In his turn, Muhammad then emerged as an adored man, not only because of his struggles, but also his noble attitude and morality. It is important to note that Muhammad went through the process, step by step, to direct him to be a very successful man.

His business character had been developed since he was very young; when he was only 12 years old. Coming from a poor family, Muhammad decided to be

\footnotetext{
13Karen Armstrong, Sejarah Tuhan (Bandung: Mizan, 2004), p. 190.

${ }^{14}$ Emha Ainun Nadjib, Nasionalisme Muhammad (Yogyakarta: Sippres, 1995), p. 7.

15Muhammad Husain Haekal, Sejarah Hidup Muhammad (Bogor: Litera Antar Nusa, 1990), p. 78.
} 
an independent and hardworking individual, which led him to follow his uncle's footstep to be a merchant. He went on trading expedition to places outside Arab. He was the only teenagers at that time, but it did not discourage him to learn the skills and to work hard for his success.

For Muhammad, business was not based on cash. The primary capitals in his business were trust and trustworthiness. When someone trusted him, with his honest character, he proved his skills and his worth in his field of work. Muhammad followed his own discipline in conducting business. He became success, not inherited it. The winning principle in Muhammad's celestial business was that he did not ignore the world to pursue the hereafter rewards, nor did he forget religious purposes for the worldly success. He was never a burden, let alone a parasite, for others. What Muhammad practiced is called as Celestial Business in this paper.

\section{The Development Of Islamic Society Based on Celestial Business}

The concept of 'Celestial Business' is inspired by the concept of 'Celestial Management' proposed by A. Riawan Amin, the General Director of Bank Muamalat Indonesia ${ }^{16}$. He implemented this concept in the managerial system of his bank. He proposes three main pillars in Celestial Management; calling them 'ZIKR', 'PIKR', and 'MIKR'.

The first principle, ZIKR, consists of Zero Base, Iman (Faith), Konsisten (Consistency), and Result Oriented. This first principle is the manifestation of 'place of worship.' Zero Base is a reflection of being sincere as taught in AlQur'an; which is a belief that everything belongs to Allah and will go back to Allah. ${ }^{17}$ Iman or Faith is the key, as well as the foundation, of all activities. Konsistensi (Consistency) is a manifestation of the concept of Istiqomah (being consistent). ${ }^{18}$ Meanwhile, Result Oriented is the realization of the concept of being patient (in a process) and having faith towards Allah's design.

\footnotetext{
${ }^{16}$ A. Riawan Amin, The Celestial Management (Jakarta: Senayan Book, 2007).

${ }^{17}$ QS. al-Baqarah [2]: 156.

${ }^{18} \mathrm{QS}$. al-Ahquāf [46]: 16.
} 
The second principle, PIKR, is an acronym of 'Power', 'Information', 'Knowledge', and 'Rewards' as the manifestation of 'place of wealth'. These four aspects are the key pillars in the practical-operational level of a management. A. Riawan Amin believes that the celestial management will not work without these four things.

The third principle, MIKR, stands for being 'Militant', 'Intellectual', 'Competitive' and 'Regenerative', a manifestation of "place of warfare". A manager has to possess these traits in performing all his managerial activities.

These three principles are designed as the key pillars of the Celestial Management. In the practical-operational level, these principles are based on the personality of Muhammad as a successful manager. Through the same approach (elaborative-reflective thinking), the concept of Celestial Business attempts to define business based on Al-Qur'an and hadiths, and refer to the Prophet Muhammad as the ideal prototype of a spiritual businessman.

Aside from his success as a Prophet who succeeded to expand the great civilization of Islam in a relatively short time through spiritual leadership, Muhammad was also a successful businessman with his spiritual entrepreneurship. In fact, Laode Kamaludin believed that Muhammad had successfully developed a mega-business that always profited in the whole human history. This proved the success of Muhammad's leadership. In the field of economy, as Kamaludin stated, Muhammad was also a successful merchant. ${ }^{19}$

Talking about the business secret of the Prophet Muhammad as a successful entrepreneur, there are at least six formulas that can be used as the main formula of Celestial Business. They are:20 1) Making a job as the field to pursue divine rewards. 2) Honesty and trustworthiness are important capitals in doing business. In this context, Muhammad's reputation in honest is undisputable. He even got the nickname 'Al-Amin' or The Honest-One (Mr. Clean). 3) Having targets and attempt to achieve them. 4) Thinking visionary and creatively, as well as being prepared to face changes. For the Prophet Muhammad, changes to be better in the future are absolute certainty. 5) Prioritizing synergy and network.

${ }^{19}$ Laode M. Kamaludin, Rahasia Bisnis Rasulullah (Bandung: Azzam Publishing, 2007), p. 39.

${ }^{20}$ Joko Syahban, Berbisnis Bersama Tuhan (Jakarta: Hikmah, 2008), p. 10. 
This is reflected in one of the hadiths; "anyone who wants to have his provisions expanded and his term of life prolonged should maintain ties of kinship" (HR. Muslim, from Anas bin Malik). 6) Attempting to be the best and useful man, and always be grateful toward Allah.

These six business secrets of the Prophet Muhammad can be the formula for the Celestial Business. These principles have two sides: the worldly and the heavenly sides, or the material and spiritual; which will solve the problems of modern discrepancy and imbalance in pursuing success as Robert Holder and David Cheney note.

As previously stated Celestial Business (al-mubaya'ah as-samawiyah) is a concept that require equilibrium or balance in the satisfaction of physical and psychological, material and spiritualneeds. Joko Syahban ${ }^{21}$ called Celestial Business as 'doing business with God.'

The balanced needs of physical and spiritual aspects, as noted by Zohar and Marshall ${ }^{22}$, are an absolute necessity for today's modern society, including in the field of economy and business. Such equilibrium, as Muhammad Ali AlHashimi ${ }^{23}$ stated, is the most distinctive trait of Islamic economy.

Spirituality in economy and business serves as guidance for the efforts of humanization and transcendence of business and economy, so that they are not trapped in individualism and selfishness which will put economic circumstances into the abyss of diametric irony; the poor subsidizing the rich. When this happens, humanism of economy is gone. There will be no realization of "wa ashen Kama asana Allah ilea" (do good to others as Allah does good to you), and economic circumstances will become a field of inhuman and deathly competition.

At this point, a preliminary conclusion can be drawn that Celestial Business is an elaborative-reflective effort on the business and religious values-in this case are the Islamic values stated in Al-Qur'an and Sunnah. This elaboration, in its turn, requires a balanced satisfaction of physical and spiritual needs. The

\footnotetext{
21Joko Syahban, Berbisnis Bersama Tuhan (Jakarta: Hikmah, 2008).

${ }^{22}$ Danah Zohar and Ian Marshall, Spiritual Intelligence The Ultimate Intelligence (London: Bloomsbury, 2000).

${ }^{23}$ Muhammad 'Ali Al-Hashimi, The Ideal Muslim Society (Riyadh: International Islamic Publsihing House, 2007), p. 287.
} 
business values will satisfy the physical and material needs, while the religious values will satisfy the psychological and spiritual needs.

Besides, according to Afzalurrahman, ${ }^{24}$ the balance in business is also a manifestation of the message embedded in the hadith, "work for your worldly life as if you are living forever, and work for your Hereafter as if you are dying tomorrow."

Normatively, the concept of Celestial Business refers to al-Qur'an surah alḤadīd: 25, which states:

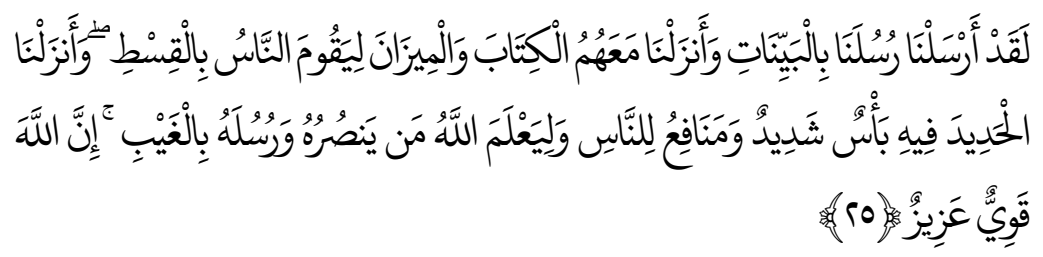

"We have already sent Our messengers with clear evidences and sent down with them the Scripture and the balance that the people may maintain [their affairs] in justice. And We sent down iron, wherein is great military might and benefits for the people, and so that Allah may make evident those who support Him and His messengers unseen. Indeed, Allah is Powerful and Exalted in Might."

Referring to scientific interpretation of this verse, there are at least three key words in the economic principle of Muhammad: Scripture, justice, and iron.

"Scripture" refers to the phrase "wa anzalnā ma'ahum I-kitāb," as a symbol of spirituality, morality, and good example. "Justice" (al-mizan) is the symbol of fairness, accountability, and transparency. While the principle of "iron", referring to the phrase "wa anzalnā al-ḥadīda ba'sun shadīdun wa manāfi'un li 'n-nās," is a symbol of 'power'.25

Muhammad's business was conducted in the practical-operational level based on these three principles. The most fundamental of them is the 'Scripture' principle. It is no wonder that Muhammad's economy is performed with the highest sense of morality, spirituality, and good examples. The nickname 'al-

\footnotetext{
${ }^{24}$ Afzalur Rahman, Muhammad as a Trader: from Encyclopedia of Seerah (London: The Muslim School Trust, 1982).

25Ibid., p. 73
} 
amin' (the honest one) has shown that Muhammad is an economic actor who upholds the ethical values.

The second principle, 'justice', is an undisputable factor in Muhammad's business. Meanwhile, the third principle is agreed by other economic ideology. Power is a determining factor for the success of a system.

We can see that celestial business as practiced by Muhammad can indeed be the ideal option or the 'third way' to solve the economic problems of Islamic society. Today, the most fundamental problem of our global economy is the 'mor( $t$ )ality'; i.e. the death of morality as the main pillar of humanistic economy. Consequently, justice is a far cry in economy. To solve this problem, the economy of Muhammad offers a solution through its two principles-the Scripture and the justice.

Celestial Business emphasizes that every Moslem individual should become a person who comes, trades, and wins, like Muhammad. Balance is the main point of celestial business. Islam does not desire materialism, in which everything is viewed form the materialistic perspective. Materialism occurs when 'usefulness' is considered the most important aspect of all. Islam also does not want any imagology, in which everything is viewed based on its image. Imagology, according to Milan Kundera, occurs when everything is valued based on its mere image. ${ }^{26}$

Here is where celestial business can be the 'mid-way' that provides balance between the value of 'usefulness' and the value of 'image'. Islam has an alternative model of economy that considers the 'functional reason'-as the socialists want-and the 'image reason' or 'status reason' - as the capitalists concern about. Islam put those two economic values in a similar proportion. Islam maintains the importance of 'usefulness' as well as 'image', provided that it does not become an imagology. Islam also introduces another value, i.e. the social ethic. In this context, Islamic enculturation on local values creates a reproduction of local cultures that conform to the fundamental value in alQuran, which is tauhid (believing in the one God).27

\footnotetext{
26Idy Subandi Ibrahim, Lifestyle Ecstasy: Kebudayaan Pop dalam Masyarakat Komoditas Indonesia (Bandung: Mizan, 1997).

${ }^{27}$ Ali Sodiqin, Antropologi al-Qur'an: Model Dialektika Wahyu dan Budaya (Yogyakarta: Arruz Media), p. 214
} 
Conceptually, Celestial Business provides a balance, economic morality, and social orientation, while not forgetting the individual rights. Islamic economy is the answer as well as the way to reshape the global macro-economy. It also proves that the values of Islamic economy are always actual, and can solve the problems of economic discrepancy. Celestial Business should be the reference to develop Islamic society in its effort to achieve economic prosperity.

\section{Conclusion}

Considering the scarcity of references on society development strategies and models, the existence of a model based on celestial business development can be the solution. Conceptually, the formula of celestial business (doing business with God) is in line with Islamic teaching that emphasizes the balance of material and spiritual aspects, which makes it relevant to implement in the context of the development of economic aspect of Islamic society. This formula provides an equilibrium between the satisfaction of physical and psychological, material and spiritualneeds. On the higher level, this formula can be an alternative to develop Islamic society, especially its economy. To complete the existing formula, further academic study and innovation are needed. Through this way, the scarcity of references on Islamic society development models and strategies can be solved gradually.[w] 


\section{BIBLIOGRAPHY}

Aldin, Alfathri, Resistensi Gaya Hidup: Teori dan Realitas, Yogyakarta: Jalasutra, 2006.

Amin, A. Riawan, The Celestial Management, Jakarta: Senayan Book, 2007.

Armstrong, Karen, Sejarah Tuhan, Bandung: Mizan, 2004.

Chaney, David, Lifestyles: Sebuah Pengantar Komprehensif, Yogyakarta: Jalasutra, 1996.

Dahana, Radhar Panca, Inikah Kita, Mozaik Manusia Indonesia, Yogyakarta: Resist Book, 2007.

Donohue, John J. \& John L. Esposito, Islam dan Pembaharuan: Ensiklopedi Masalah-masalah, Jakarta: Rajawali, 1984.

Haekal, Muhammad Husain, Sejarah Hidup Muhammad, Bogor: Litera Antar Nusa, 1992.

al-Hashimi, Muhammad 'Ali, The Ideal Muslim Society, Riyadh: International Islamic Publsihing House, 2007.

Holden, Robert, Success Intelegence, Bandung: Mizan, 2005.

Ibrahim, Idy Subandy, Lifestyle Ecstasy: Kebudayaan Pop dalam Masyarakat Komoditas Indonesia, Bandung: Mizan, 1997.

Kamaludin, Laode M., Rahasia Bisnis Rasulullah, Bandung: Azzam Publishing, 2007.

Mulkhan, Abdul Munir, Teologi Kebudayaan, Yogyakarta: Sipress, 1995.

Nadjib, Emha Ainun, Nasionalisme Muhammad, Yogyakarta: Sipress, 1995.

Perkins, John, Confession of Economic Hitman, London: Routledge, 2000.

Rahman, Afzalur, Muhammad as a Trader: from Encyclopedia of Seerah, London: The Muslim School Trust, 1982.

Rakhmat, Jalaluddin, Catatan Kang Jalal: Visi Media, Politik, dan Pendidikan, Bandung: Rosdakarya, 1997.

Rais, Amien, Agenda Mendesak Bangsa: Selamatkan Indonesia, Yogyakarta: PPSK, 2003. 
Shihab, Quraish, Membumikan al-Qur'an, Bandung: Mizan, 2005.

Sodiqin, Ali, Antropologi al-Qur'an: Model Dialektika Wahyu dan Budaya, Yogyakarta: Arruz Media, 2008.

Syahban, Joko, Berbisnis Bersama Tuhan, Jakarta: Hikmah, 2008.

Wiliam J. Bamoul, R. E. Litian, C. J. Schramm, Good Capitalism, Bad Capitalism, New Haven \& London: Yale University Press, 2005.

Zohar, Danah \& Ian Marshall, Spiritual Intelligence The Ultimate Intelligence, London: Bloomsbury, 2000. 
